\title{
Morphological Characterization of Goat Populations in Central Zone of Tigray, Ethiopia
}

\author{
M. Birhanie ${ }^{\mathrm{a}, *}$, K. Alemayehu ${ }^{\mathrm{b}}$, \& G. Mekuriaw ${ }^{\mathrm{b}, \mathrm{c}}$ \\ aTigray Agricultural Research Institute, Abergelle Center, Abi-Adi, Ethiopia \\ ${ }^{b}$ Department of Animal Production and Technology, Bahir Dar University, Bahir Dar, Ethiopia \\ cDepartment of Animal Breeding and Genetics, Swedish University of Agricultural Sciences, Uppsala, Sweden \\ *Corresponding author: msmini2001@gmail.com \\ (Received 27-01-2019; Revised 15-04-2019; Accepted 23-04-2019)
}

\begin{abstract}
Ethiopia has huge livestock resource, but poor in their productivity. It stated national small ruminant breeding policy and strategy focused on genetic improvement. This is intended to design appropriate breeding programs based on the indigenous breeds status. Study of phenotypic variation is among the prerequisite activities of genetic improvement that is limited in this study area. The objective of this study was to describe morphological characteristics and variations of goat populations in the Central zone of Tigray. Qualitative and quantitative data of 403 young to matured goats (326 lactating does and 77 bucks) were used to analyze by frequency procedure, GLM procedure, Pearson correlation, and multivariate analysis of SAS version 9.4. The study revealed that goats in Adwa district were distinct in coat colors and pattern, horn shape, ear orientation, head profile and ruff, significantly heavier $(\mathrm{p}<0.01)$ and larger $(\mathrm{p}<0.001)$ in height at withers and in height at pelvic than those in Tanqua Abergele (TA) and Kola Tembien (KT) districts. Goats found in Adwa district were morphologically distinct from those found in TA and KT districts with the higher discriminating values in female goats.
\end{abstract}

Keywords: body weight; goat; linear measurements; morphology

\section{INTRODUCTION}

Livestock production is mainstay agricultural sector in Ethiopia (CSA, 2017). It sustains the livelihood of smallholder rural people (Leta \& Mesele, 2014) and contributes an estimated $35 \%-49 \%$ of national agricultural GDP (Endalew \& Ayalew, 2016) Large population and diversity are the main resource of this sector due to geographical proximity to the gateway of many livestock populations from Asia and have diverse agroecological zones. Although it needs comprehensive work to identify the diversity, phenotypically 34 cattle, 12 goats, and 12 sheep breeds or populations are registered in DAGRIS (2018).

Goats are an important species for the livelihood of rural people in providing predominantly meat, milk, and cash income (Kosgey et al., 2006). Goat is preferred for resource-poor farmers, since easier to acquire, easier to maintain, prolific, early mature and adaptable to the harsh environment (Kumar et al., 2010; Sousa et al., 2011). Goat population is accounted for 29.70 million in Ethiopia (CSA, 2017). A larger population with higher flock size of goats is found in the arid and semi-arid lowland areas of the country where crop production is low or unreliable by providing 3.4 and 1.6 times higher gross margin than sheep and cattle, respectively (Woldu et al., 2016).

Despite huge resource of goats in the country, their productivity is below the expectation. This below expectation production is due to feed shortage, disease, inferior genotype, and market access (Mekuriaw et al., 2016). Recently, the country's Minister of Agriculture stated national small ruminant breeding policy and strategy to improve productivity through breeding programs. Knowing morphological character and their variations among and within goat populations is an alternative option and important input to design effective breeding programs (FAO, 2012; Hosseini et al., 2016; Lestari at al., 2018).

As a result, phenotypic characterization of goats has been conducted in different parts of the country after FARM-Africa was physically identified in 1994. Some parts of this study area were delineated as the habitat of Abergelle and Central Highland goat populations by FARM-Africa. However, recent information on morphological or phenotypic traits performance and their variations among and within the populations towards genetic improvement is very limited in this study area. Therefore, this study aimed to describe the morphological characteristics of the goat populations in the central zone of Tigray.

\section{MATERIALS AND METHODS}

\section{Description of the Study Areas}

The study was conducted in Tanqua Abergele (TA), Kola Tembien (KT) and Adwa districts located 
in the Central zone of Tigray, Ethiopia at $13^{\circ} 47^{\prime} 6^{\prime \prime}$ $\left(13.78507^{\circ}\right) \mathrm{N}$ latitude and $38^{\circ} 49^{\prime} 14^{\prime \prime}\left(38.82054^{\circ}\right) \mathrm{E}$ longitude (Figure 1). Tanqua Abergele (TA) district is found $120 \mathrm{~km}$ far from the Mekelle city of Tigray National Regional State. It has an area coverage of 240,788 hectares (CSA, 2007). Around $87.36 \%$ of the area is cultivation land in cereals, pulses, and oilseeds and the remained percentage is pasture, fallow, and the others with 1.63 hectares average land per household (CSA, 2001). The main feeding system and feeds are browsing natural pastures and stubble grazing with a little supplementation of crop residues and hay (Tajebe \& Kebede, 2011; Gebremariam \& Belay, 2016). Kola Tembien (KT) district is adjacent to TA district and 103 $\mathrm{km}$ far from Mekelle city. It has an area coverage of 253,839 hectares (CSA 2007). Around $85.28 \%$ of the area is cultivation land in cereals, pulses, and oilseeds and the remined percentage is for pasture, fallow, woodland, and the others with an average land per household of 0.81 hectares (CSA, 2001). TA and KT districts are categorized as a hot to warm sub-moist lowland (SM1-4) sub-agroecology zone due to their climatic conditions (Table 1) (MoA, 1998). Whereas Adwa district is found $225 \mathrm{~km}$ far from Mekelle city. The district has an area coverage of 188,860 hectares (CSA, 2007), $89.75 \%$ of the area is cultivation land in cereals, pulses, and oilseeds and the remained percentage is pasture, fallow, and woodland (CSA, 2001). It was categorized as midland agroecology conditions (Table 1) (MoA, 1998). Crop residues $(>50 \%)$, grazing land $(<25 \%)$, and hay $(<25 \%)$ are the main feed sources of Adwa district with feeding management of browsing and supplementation of crop residues and hay (Tesfay et al., 2016).

\section{Data Types and Collection Methods}

Morphological quantitative and qualitative data were collected from 403 (326 lactating does and 77 bucks) randomly selected by measuring and observation, respectively during pick kidding months (October to December 2017) on farm gate in the morning. The age of sampled goats was categorized as yearling (1-2 years old), young adult (2-3 years old), adult (3-4 years old), and matured (4-5 years old) estimated by dentation as 1 , 2, 3 and 4 pair of permanent incisors (PPI), respectively using FAO (2012). The measured quantitative traits were body weight, body length, height at withers, chest girth, pelvic width, chest width, rump length, height at pelvic, rear udder diameter, rear udder length, udder circumference, teat length, scrotal length, scrotal width, and scrotal circumference (Figure 2). The observed qualitative traits were coat color, color pattern, head profile, ear orientation, horn orientation, ruff, wattle, beard, back profile, horn shape, and rump profile.

\section{Data Management and Analysis}

Statistical Analysis System (SAS) version release 9.4 was used for preliminary data test and main data analysis. Qualitative traits separately for bucks and

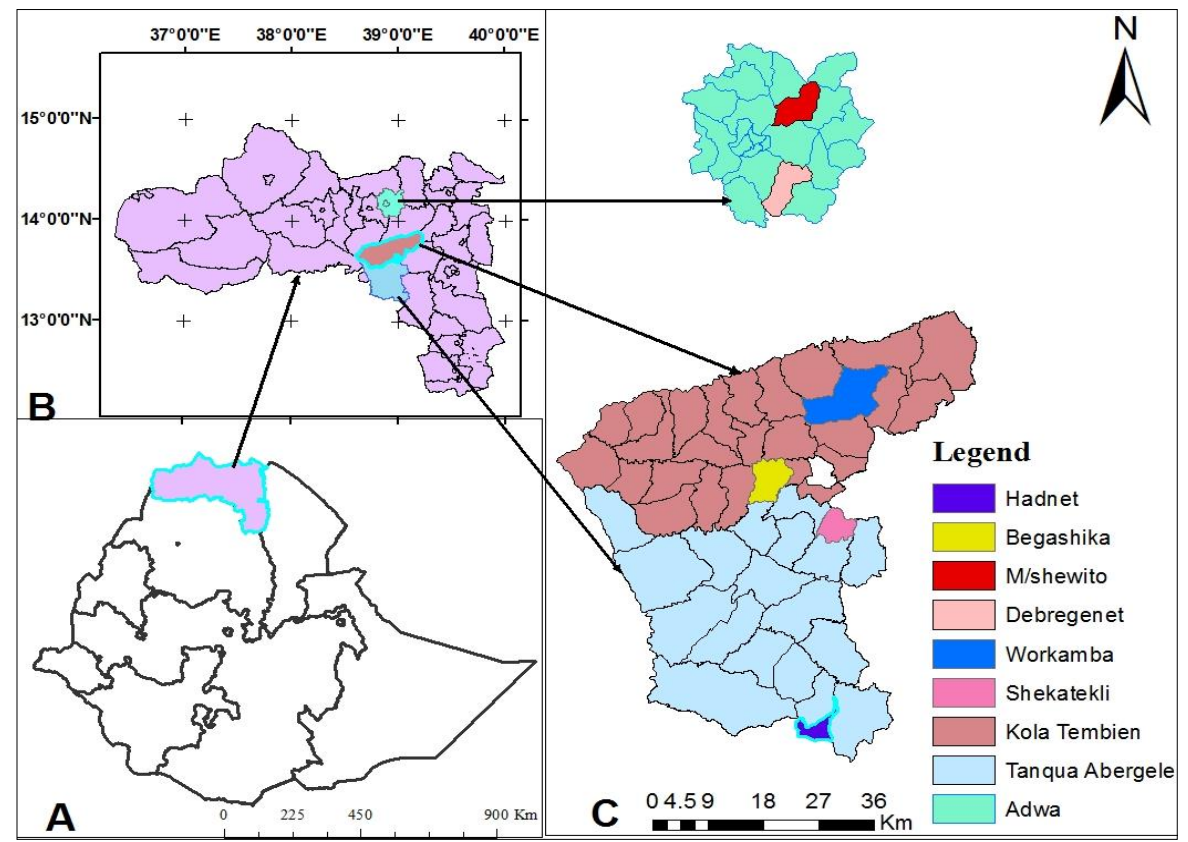

Figure 1. Study areas map: Ethiopia (A), Tigray region (B) and districts with villages (C)

Table 1. Agroecology and goat population of study areas

\begin{tabular}{lcccc}
\hline Districts & Altitude & Temperature & Annual rainfall & Goat population (heads) \\
\hline Tanqua Abergele (TA) & $1300-1500$ masl & $28-42{ }^{\circ} \mathrm{C}$ & $400-600 \mathrm{~mm}$ & 247,540 \\
Kola Tembien (KT) & $1600-1750 \mathrm{masl}$ & $13-32^{\circ} \mathrm{C}$ & $500-800 \mathrm{~mm}$ & 260,000 \\
Adwa & $1650-2258 \mathrm{masl}$ & $12-27^{\circ} \mathrm{C}$ & $600-850 \mathrm{~mm}$ & 96,409 \\
\hline
\end{tabular}



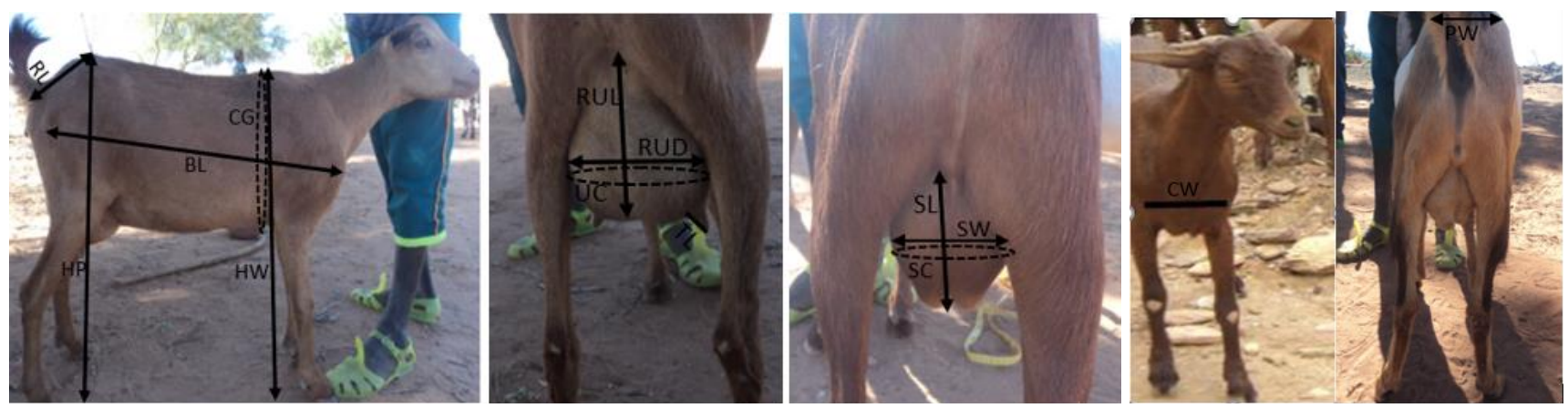

Figure 2. Pictorial description of phenotypic parameter measurements. $\mathrm{BL}=$ body length; $\mathrm{HW}=$ height at wither; $\mathrm{CG}=$ chest girth; $\mathrm{PW}=$ pelvic width; $\mathrm{CW}=$ chest width; $\mathrm{RL}=$ rump length; $\mathrm{HP}=$ height at pelvic; $\mathrm{RUD}=$ rear udder diameter; $\mathrm{RUL}=$ rear udder length; $\mathrm{UC}=$ udder circumference; $\mathrm{TL}=$ teat length; $\mathrm{SL}=$ scrotal length; $\mathrm{SW}=$ scrotal width; $\mathrm{SL}=$ scrotal circumference.

does within population and overall were analyzed using PROC FREQ of descriptive statistics. Multiple correspondence analysis was carried out to evaluate the typical features or associations of each district sampled goats. Whereas the quantitative data on live body weight, linear body, udder, and scrotal measurements were analyzed using PROC GLM. District, sex, and age groups were fitted as a fixed effect while the measurements were fitted as dependent variables. When the analysis of variance declares significance, least square means and respective standard error were separated using the Tukey-Kramer test. The model was:

$$
y_{i j k}=\mu+d_{i}+s_{j}+a_{k}+e_{i j k}
$$

where: $y_{i j k}=$ the observed body weight and linear measurements; $\mu=$ overall mean; $d=$ is the effect $\mathrm{i}^{\text {th }}$ of district (TA, KT, and Adwa); $s=$ is the effect $j^{\text {th }}$ of sex (does and bucks); $a_{K}=$ is the effect $k^{\text {th }}$ of age group (1PPI, 2PPI, $3 \mathrm{PPI}$, and $4 \mathrm{PPI}$ ), and $e_{i j k}$ is the random residual error.

Correlations of the quantitative variables were computed using Pearson's correlation coefficients separately for each sex. In addition, to identify the highly discriminate variables and their level of differences the stepwise discriminate analysis and canonical discriminate analysis of SAS were used.

\section{RESULTS}

\section{Qualitative Traits Description of Goat}

All the proportion of observed qualitative traits of sampled goats is presented in Table 2. Goats in TA and KT districts had predominantly red and red with white in dominant patterns of plain and patchy, a combination of straight and curved horn shape. While goats in Adwa district were showed predominantly red, red with black, red with white and grey in the pattern of patchy and plain, and straight horn shape.

Head profile of goats in TA was displayed predominantly straight, whereas in KT and Adwa were observed in the combination of straight and concave. Wattle, ruff, and beard were almost absent in all goat populations. Horizontal ear orientation and straight back profile were predominantly observed in all populations; however, rump profile was in different proportions among all districts.
Furthermore, the observed qualitative traits of sampled goats of both sexes were classified by $16.71 \%$ of the total variations $(8.87 \%$ and $7.84 \%$ in the first and second dimensions, respectively) (Figure 3 ). On the identified dimensions, goats in TA and KT districts were associated together with coat colors of red and grey displayed on the plain pattern, horns oriented backward, ears oriented erect, sloppy rump profile, and straight to bent down the back profile. Whereas goats in Adwa district were associated with collection coat colors of red, white, black, and grey displayed on patchy, curved horn shape, ear oriented horizontal, concave head profile and without ruff.

\section{Body Weight and Linear Measurements of Goats}

District, sex, and age effects were showed to have significant differences on body weight and linear measurements (Table 3). Goats found in Adwa district were significantly heavier $(p<0.01)$ and larger $(p<0.001)$ in height at withers and in height at pelvic than both of goat populations found in TA and KT districts. However, goats in Adwa were significantly $(p<0.01)$ wider in chest girth than goats in KT. On the other hand, goats in KT and TA districts differed in pelvic width, rump length, and pelvic width.

Bucks were significantly $(\mathrm{p}<0.001)$ heavier and larger in body weight and linear measurements except in pelvic width and rump length than counterpart does. Besides, it revealed that the body weight and all linear body measurements were showed significantly $(p<0.001)$ increased from 1PPI to 4PPI age categories.

From the observed quantitative traits, only nine in does and four in bucks were significantly $(\mathrm{p}<0.15)$ discriminated and chronologically selected from 0.83 to 0.44 and 0.59 to 0.26 Wilk's Lambda values, respectively (Table 4). The Wilks' lambda test for the discriminated traits among the districts was significant $(p<0.01)$ for both sexes (Table 5). This result indicates that all the means of discriminating variables in district factor are different. Wilks' Lambda is the ratio of within-population variability of the total variability of the discriminator variables. It is an inverse measure of the importance of the discriminant functions. In this case, the value of Wilks' Lambda for the does and bucks among districts were $44.78 \%$ and $26.22 \%$, respectively. This shows 
Table 2. Description of qualitative traits of goat populations in the study areas

\begin{tabular}{|c|c|c|c|c|c|}
\hline \multirow{2}{*}{ Traits } & \multirow{2}{*}{ Levels } & Tanqua Abergele (TA) & Kola Tembien (KT) & Adwa & Overall \\
\hline & & $\mathrm{N}(\%)$ & $\mathrm{N}(\%)$ & $\mathrm{N}(\%)$ & $\mathrm{N}(\%)$ \\
\hline \multirow[t]{9}{*}{ Coat color } & White (W) & $5(3.13)$ & $7(5.79)$ & $3(2.46)$ & $15(3.72)$ \\
\hline & $\operatorname{Red}(\mathrm{R})$ & $65(40.63)$ & $46(38.02)$ & $26(21.31)$ & $137(34)$ \\
\hline & Black (B) & $17(10.63)$ & $8(6.61)$ & $2(1.64)$ & $27(6.7)$ \\
\hline & Grey & $12(7.5)$ & $15(12.40)$ & 19(15.57) & $46(11.41)$ \\
\hline & $\mathrm{R}+\mathrm{W}$ & 31(19.38) & $27(22.32)$ & $25(20.49)$ & $83(20.6)$ \\
\hline & $\mathrm{R}+\mathrm{B}$ & $9(5.63)$ & $7(5.79)$ & $23(18.85)$ & $39(9.68)$ \\
\hline & $\mathrm{W}+\mathrm{B}$ & $15(9.38)$ & $4(3.31)$ & $6(4.92)$ & $25(6.2)$ \\
\hline & $\mathrm{W}+\mathrm{R}+\mathrm{B}$ & $2(1.25)$ & $3(2.48)$ & $6(4.92)$ & $11(2.73)$ \\
\hline & Grey with others & $4(2.5)$ & $4(3.31)$ & $12(9.84)$ & $20(4.96)$ \\
\hline \multirow[t]{3}{*}{ Color pattern } & Plain & $76(47.5)$ & $58(47.93)$ & $40(32.79)$ & 174(43.18) \\
\hline & Patchy & $71(44.38)$ & $56(46.28)$ & $69(56.56)$ & $196(48.64)$ \\
\hline & Spotted & $13(8.13)$ & $7(5.79)$ & $13(10.66)$ & $33(8.19)$ \\
\hline \multirow[t]{2}{*}{ Head profile } & Straight & $146(91.25)$ & $93(76.86)$ & $92(75.41)$ & $331(82.13)$ \\
\hline & Concave & $14(8.75)$ & $28(23.14)$ & $30(24.59)$ & 72(17.87) \\
\hline \multirow[t]{2}{*}{ Ear orientation } & Erect & $10(6.25)$ & $7(5.79)$ & $0(0.00)$ & $17(4.22)$ \\
\hline & Horizontal & 150(93.75) & $114(94.21)$ & $122(100)$ & $386(95.78)$ \\
\hline \multirow[t]{3}{*}{ Horn orientation } & Lateral & $4(2.5)$ & $3(2.48)$ & $0(0.00)$ & $7(1.74)$ \\
\hline & Upward & $54(33.75)$ & $21(17.36)$ & $20(16.39)$ & $95(23.57)$ \\
\hline & Backward & $102(63.75)$ & $97(80.17)$ & $102(83.61)$ & $301(74.69)$ \\
\hline \multirow[t]{3}{*}{ Horn shape } & Straight & $75(46.88)$ & $46(38.02)$ & $33(27.05)$ & $154(38.21)$ \\
\hline & Curved & $65(40.63)$ & $77(61.98)$ & $89(72.95)$ & $229(56.82)$ \\
\hline & Spiral & $22(12.5)$ & $0(0.00)$ & $0(0.00)$ & 20(4.96) \\
\hline \multirow[t]{2}{*}{ Wattle } & Present & 19(11.88) & $2(1.65)$ & 13(10.66) & $34(8.44)$ \\
\hline & Absent & 141(88.13) & 119(98.35) & $109(89.34)$ & $369(91.56)$ \\
\hline \multirow[t]{2}{*}{ Beard } & Present & $41(25.63)$ & $27(22.31)$ & $24(19.67)$ & $92(22.83)$ \\
\hline & Absent & $119(74.38)$ & $94(77.69)$ & 98(80.33) & $311(77.17)$ \\
\hline \multirow[t]{2}{*}{ Ruff } & Present & $28(17.5)$ & $20(16.53)$ & $20(16.39)$ & $68(16.87)$ \\
\hline & Absent & $129(82.5)$ & 91(83.47) & $102(83.61)$ & $332(83.13)$ \\
\hline \multirow[t]{3}{*}{ Back profile } & Straight & $160(100)$ & $110(90.91)$ & $102(83.61)$ & $372(92.31)$ \\
\hline & Slightly bent & $0(0.00)$ & $7(5.79)$ & $20(16.39)$ & $27(6.7)$ \\
\hline & bent down & $0(0.00)$ & $4(3.31)$ & $0(0.00)$ & $4(0.99)$ \\
\hline \multirow[t]{3}{*}{ Rump profile } & Flat & $1(0.63)$ & $0(0.00)$ & $4(3.28)$ & $5(1.24)$ \\
\hline & Sloppy & $103(64.38)$ & $53(43.80)$ & $70(57.38)$ & $226(56.08)$ \\
\hline & Roof & $58(35)$ & $68(56.20)$ & $48(39.34)$ & $172(42.68)$ \\
\hline
\end{tabular}

Note: $\mathrm{N}=$ Number, $\mathrm{R}+\mathrm{W}=$ Red with White, $\mathrm{R}+\mathrm{B}=$ Red with Black, $\mathrm{W}+\mathrm{B}=$ White with Black, $\mathrm{W}+\mathrm{R}+\mathrm{W}=\mathrm{White}$, Red, and Black.

$56.22 \%$ and 73.78 of the difference in the discriminating variables were among districts for does and bucks, respectively. Whereas the remaining percentage $(44.78 \%$ and $26.22 \%$ ) of differentiation was within the district. In fact, the higher percentage of differentiation within the population of the district is occurred due to age differences.

The variation distance of sampled goats among the districts was highly significant $(p<0.001)$ (Table 6). This showed the existence of measurable differences among districts' goat population. The observed differences were 13.52 TA with Adwa does, 10.62 KT with Adwa does, while in bucks the distance (7.61) were significant between TA and KT. The longest distance occurred between Adwa and both TA and KT districts. This result indicates that goats in TA and KT districts are similar and goats in Adwa district are different from both districts (TA and KT).

\section{Udder and Scrotal Measurements}

Like the other considered linear body measurements in this study, udder circumference, rear udder diameter, and teat length of does and scrotal length of bucks were showed to have significant difference among districts (Table 7). Does found in TA district had significantly $(\mathrm{p}<0.001)$ larger udder circumference $(31.12 \pm 0.76 \mathrm{~cm})$ and rear udder diameter $(10.67 \pm 0.28 \mathrm{~cm})$ than does found in KT and Adwa districts. However, does in Adwa district had significantly $(p<0.001)$ longer $(3.15 \pm 0.08 \mathrm{~cm})$ teat than does found in TA and KT. Unlike body weight and linear measurements (Table 3), udder and scrotal measurements except for teat length and scrotal circumference were not significantly increased in size as age increased (Table 7). 


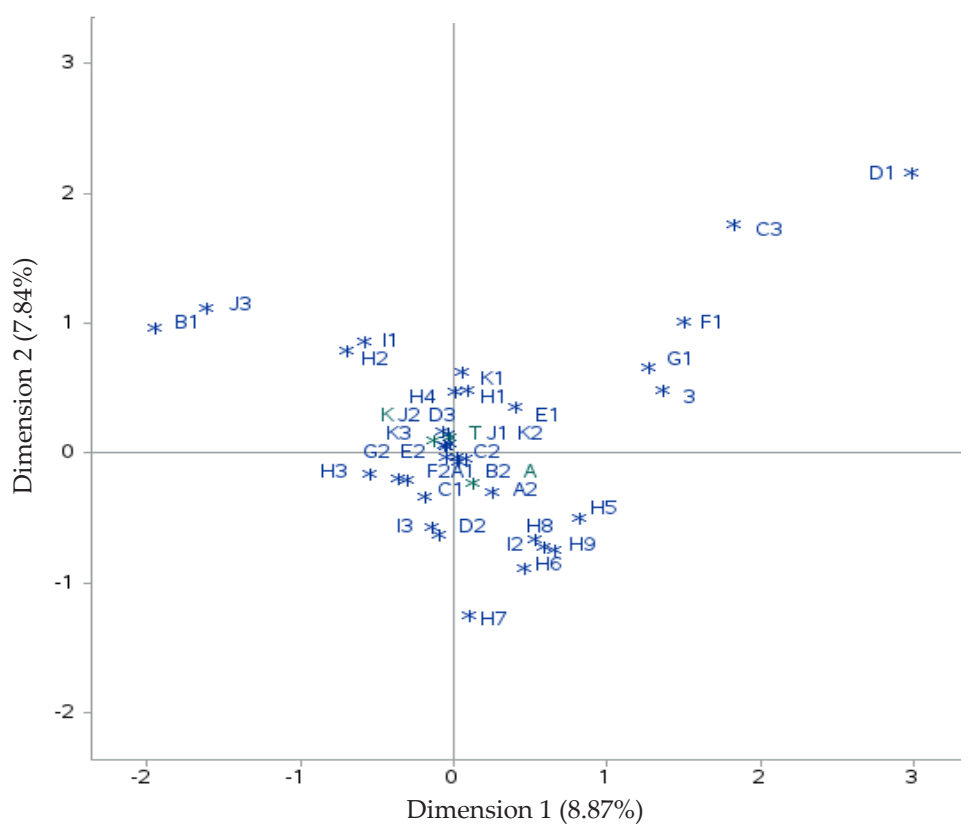

Figure 3. Bi-dimensional graph showing the association among trait levels. Districts (Tanqua Abergele $(\mathrm{TA})=\mathrm{T}, \mathrm{Kola}$ Tembien $(\mathrm{KT})=$ $\mathrm{K}, \mathrm{Adwa}=\mathrm{A})$; Head profile (Straight= A1, Concave= A2); Ear orientation (Erect= B1, Horizontal= B2); Wattle $($ Present= E1, Absent= E2); Coat colour (White= H1, Red= H2, Black = H3, Grey= H4, Red with White= H5, Red with Black= H6, White with Black= H7, White, Red and Black= H8, Grey with other= H9); Ruff (Present= F1, Absent= F2); Colour pattern (Plain= I1, Patchy= I2, Spotted= I3); Horn shape (Straight = C1, Curved= C2, Spiral= C3); Horn orientation (Lateral= D1, Upward= D2; Backward= D3); Back profile (Straight= J1, Slightly bent = J2, Bent down = J3); Rump profile (Flat= K1 Sloppy= K2, Slightly sloppy= K3); Beard (Present= G1, Absent = G2).

Table 3. Body weight and linear measurements of goats

\begin{tabular}{|c|c|c|c|c|c|c|c|c|c|}
\hline \multirow{3}{*}{$\begin{array}{c}\text { Fixed } \\
\text { variables }\end{array}$} & \multirow{3}{*}{$\mathrm{N}$} & \multicolumn{8}{|c|}{ Dependent variables } \\
\hline & & BW & BL & HW & CG & PW & $\mathrm{CW}$ & RL & $\mathrm{HP}$ \\
\hline & & $\mathrm{LSM} \pm \mathrm{SE}$ & $\mathrm{LSM} \pm \mathrm{SE}$ & $\mathrm{LSM} \pm \mathrm{SE}$ & $\mathrm{LSM} \pm \mathrm{SE}$ & $\mathrm{LSM} \pm \mathrm{SE}$ & $\mathrm{LSM} \pm \mathrm{SE}$ & $\mathrm{LSM} \pm \mathrm{SE}$ & $\mathrm{LSM} \pm \mathrm{SE}$ \\
\hline Overall & 403 & $26.03 \pm 0.31$ & $61.30 \pm 0.24$ & $65.06 \pm 0.27$ & $70.55 \pm 0.29$ & $12.94 \pm 0.10$ & $13.43 \pm 0.13$ & $15.45 \pm 0.13$ & $68.03 \pm 0.26$ \\
\hline R2 & 403 & 0.46 & 0.27 & 0.37 & 0.44 & 0.22 & 0.22 & 0.15 & 0.31 \\
\hline $\mathrm{CV} \%$ & 403 & 13.84 & 5.05 & 5.01 & 4.77 & 0.22 & 11.54 & 9.76 & 4.25 \\
\hline District & 403 & $*$ & * & $* * *$ & * & $* * *$ & $* * *$ & $* * *$ & $* * *$ \\
\hline $\mathrm{TA}$ & 160 & $25.45 \pm 0.43^{a}$ & $60.69 \pm 0.36^{a}$ & $64.99 \pm 0.37^{a}$ & $70.42 \pm 0.38^{\mathrm{ab}}$ & $12.75 \pm 0.14^{a}$ & $14.17 \pm 0.18^{\mathrm{a}}$ & $14.74 \pm 0.17^{a}$ & $67.52 \pm 0.37^{a}$ \\
\hline KT & 121 & $25.02 \pm 0.48^{a}$ & $61.35 \pm 0.40^{\mathrm{ab}}$ & $63.94 \pm 0.42^{a}$ & $69.91 \pm 0.44^{\mathrm{a}}$ & $13.44 \pm 0.15^{b}$ & $13.25 \pm 0.20^{\mathrm{b}}$ & $15.93 \pm 0.20^{\mathrm{b}}$ & $66.90 \pm 0.37^{a}$ \\
\hline Adwa & 122 & $26.51 \pm 0.42^{b}$ & $61.87 \pm 0.35^{\mathrm{b}}$ & $66.24 \pm 0.36^{b}$ & $71.32 \pm 0.38^{\mathrm{b}}$ & $12.65 \pm 0.13^{a}$ & $12.87 \pm 0.17 \mathrm{~b}$ & $15.69 \pm 0.17 \mathrm{~b}$ & $69.68 \pm 0.33^{b}$ \\
\hline Sex & 403 & $* * *$ & $* * *$ & $* * *$ & $* * *$ & ns & $* * *$ & ns & $* * *$ \\
\hline Female & 326 & $22.66 \pm 0.31^{a}$ & $59.89 \pm 0.27 \mathrm{a}$ & $62.23 \pm 0.28^{a}$ & $67.66 \pm 0.29 a$ & $12.78 \pm 0.10$ & $12.58 \pm 0.13^{a}$ & $15.26 \pm 0.13$ & $65.79 \pm 0.25^{\mathrm{a}}$ \\
\hline Male & 77 & $29.40 \pm 0.50^{\mathrm{b}}$ & $62.71 \pm 0.43^{\mathrm{b}}$ & $67.88 \pm 0.45^{b}$ & $73.44 \pm 0.47^{\mathrm{b}}$ & $13.10 \pm 0.16$ & $14.28 \pm 0.21^{\mathrm{b}}$ & $15.64 \pm 0.20$ & $70.27 \pm 0.45^{b}$ \\
\hline Age & 403 & $* * *$ & $* * *$ & $* * *$ & $* * *$ & $* * *$ & $* * *$ & $* * *$ & $* * *$ \\
\hline 1PPI & 24 & $21.02 \pm 0.85^{\mathrm{a}}$ & $57.75 \pm 0.71^{\mathrm{a}}$ & $61.20 \pm 0.73^{a}$ & $65.13 \pm 0.76^{\mathrm{a}}$ & $11.79 \pm 0.27^{a}$ & $12.29 \pm 0.35^{a}$ & $14.42 \pm 0.35^{\mathrm{a}}$ & $64.88 \pm 0.65^{a}$ \\
\hline 2PPI & 71 & $25.28 \pm 0.59^{b}$ & $61.08 \pm 0.50^{\mathrm{b}}$ & $64.90 \pm 0.51^{\mathrm{b}}$ & $69.91 \pm 0.54^{\mathrm{b}}$ & $12.96 \pm 0.19^{b}$ & $13.60 \pm 0.24^{b}$ & $15.40 \pm 0.24^{\mathrm{ab}}$ & $68.17 \pm 0.46^{\mathrm{b}}$ \\
\hline 3PPI & 111 & $27.08 \pm 0.46^{b}$ & $62.06 \pm 0.39 \mathrm{~b}$ & $66.19 \pm 0.40^{\mathrm{b}}$ & $72.32 \pm 0.42^{\mathrm{c}}$ & $13.35 \pm 0.15^{\mathrm{bc}}$ & $13.83 \pm 0.19^{b c}$ & $15.93 \pm 0.19 \mathrm{~b}$ & $68.78 \pm 0.37 \mathrm{~b}$ \\
\hline 4PPI & 197 & $30.33 \pm 0.37^{c}$ & $64.31 \pm 0.31^{\mathrm{c}}$ & $67.94 \pm 0.32^{\mathrm{c}}$ & $74.84 \pm 0.33^{\mathrm{d}}$ & $13.67 \pm 0.12^{\mathrm{c}}$ & $14.01 \pm 0.15^{\mathrm{bd}}$ & $16.06 \pm 0.15^{\mathrm{bc}}$ & $70.30 \pm 0.34^{c}$ \\
\hline
\end{tabular}

Note: BW=body weight, BL=body length, HW=height at wither, $C G=$ chest girth, $\mathrm{PW}=$ pelvic width, $\mathrm{CW}=$ chest width, RL=rump length, HP=height at pelvic, $\mathrm{TA}=$ Tanqua-Abergele, $\mathrm{KT}=$ Kola-Temben, $\mathrm{PPI}=$ pair of permanent incisors, $1 \mathrm{PPI}=$ yearling $(1-2$ years old $), 2 \mathrm{PPI}=$ young-adult $(2-3$ years old), 3PPI=adult (3-4 years old), 4PPI= matured ( $4-5$ years old) $,^{*}=p<0.05,{ }^{* *}=p<0.01,{ }^{* * *}=p<0.001$, LSM=least mean square, SE=standard error, $\mathrm{R} 2=$ Coefficient of determination for the proportion of variance in the dependent variables by independent variables.

\section{Correlation of the Quantitative Traits}

Linear udder measurements of sampled goat populations were strongly positively correlated with most linear body measurements, except with body length, rump length, and height at pelvic. While the scrotal measurements weakly and negatively correlated, except scrotal circumference with body weight, body length, height at pelvic and rump length. Amongst of the considered traits, body weight with chest girth showed strongest $(\mathrm{r}=0.86 ; \mathrm{r}=0.87)$ correlation in both sexes. Moreover, body weight with height at pelvic and withers were showed the strongest $(r=0.71 ; \mathrm{r}=0.70)$ correlation. 
Table 4. Quantitative traits selected by stepwise discriminant analysis

\begin{tabular}{|c|c|c|c|c|c|c|c|c|}
\hline Step & Entered & Partial R ${ }^{2}$ & F Value & $\operatorname{Pr}>F$ & $\begin{array}{c}\text { Wilks' } \\
\text { Lambda }\end{array}$ & $\operatorname{Pr}<$ Lambda & ASCC & $\operatorname{Pr}>$ ASCC \\
\hline \multicolumn{9}{|l|}{ Does } \\
\hline 1 & $\mathrm{CW}$ & 0.17 & 20.25 & $<.0001$ & 0.84 & $<.0001$ & 0.08 & $<.0001$ \\
\hline 2 & $\mathrm{HP}$ & 0.15 & 18.13 & $<.0001$ & 0.71 & $<.0001$ & 0.16 & $<.0001$ \\
\hline 3 & RW & 0.11 & 12.46 & $<.0001$ & 0.63 & $<.0001$ & 0.21 & $<.0001$ \\
\hline 4 & UC & 0.10 & 10.92 & $<.0001$ & 0.57 & $<.0001$ & 0.24 & $<.0001$ \\
\hline 5 & $\mathrm{TL}$ & 0.09 & 9.80 & $<.0001$ & 0.52 & $<.0001$ & 0.28 & $<.0001$ \\
\hline 6 & RUL & 0.05 & 5.74 & 0.0038 & 0.49 & $<.0001$ & 0.29 & $<.0001$ \\
\hline 7 & BW & 0.02 & 2.48 & 0.0862 & 0.48 & $<.0001$ & 0.30 & $<.0001$ \\
\hline 8 & $\mathrm{BL}$ & 0.05 & 5.51 & 0.0047 & 0.45 & $<.0001$ & 0.32 & $<.0001$ \\
\hline 9 & CG & 0.02 & 2.14 & 0.1203 & 0.44 & $<.0001$ & 0.33 & $<.0001$ \\
\hline \multicolumn{9}{|l|}{ Buck } \\
\hline 1 & $\mathrm{CW}$ & 0.40 & 6.45 & 0.0073 & 0.60 & 0.0073 & 0.20 & 0.0073 \\
\hline 2 & SL & 0.22 & 2.54 & 0.1072 & 0.46 & 0.0068 & 0.29 & 0.0107 \\
\hline 3 & RW & 0.21 & 2.27 & 0.1341 & 0.37 & 0.0063 & 0.35 & 0.0115 \\
\hline 4 & $\mathrm{BL}$ & 0.29 & 3.20 & 0.0679 & 0.26 & 0.0030 & 0.45 & 0.0056 \\
\hline
\end{tabular}

Note: $\mathrm{CW}=$ chest width, $\mathrm{HP}=$ height at pelvic, $\mathrm{UC}=$ udder circumference, $\mathrm{TL}=$ teat length, $\mathrm{RUL}=$ rear udder length, $\mathrm{BW}=\mathrm{body}$ weight, $\mathrm{BL}=\mathrm{body}$ length, $\mathrm{CG}=$ chest girth, $\mathrm{SL}=$ scrotal length, $\mathrm{R}^{2}=$ Coefficient of partial determination for the proportion of variance in the dependent variables by independent variables.

Table 5. Multivariate statistics

\begin{tabular}{ccccccc}
\hline Test statistics & Sex & Test Value & F Value & Num DF & Den DF & Pr $>$ F \\
\hline Wilks' Lambda & For Does & 0.4478 & 9.69 & 20 & 392 & $<.0001$ \\
& For Bucks & 0.2622 & 3.81 & 8 & 32 & 0.003 \\
\hline
\end{tabular}

Note: Num DF= The numerator degrees of freedom of the F-value corresponding to this test; Den DF= The denominator degrees of freedom of the F-ratio corresponding to this test.

Table 6. Squared mahalanobis distance among districts

\begin{tabular}{lccc}
\hline \multicolumn{1}{c}{ District } & TA & KT & Adwa \\
\hline TA & 0 & $5.87^{* * *}$ & $13.52^{* * *}$ \\
KT & $1.46^{\mathrm{ns}}$ & 0 & $10.62^{* * *}$ \\
Adwa & $7.61^{* *}$ & $2.75^{\mathrm{ns}}$ & 0 \\
\hline
\end{tabular}

Note: $\mathrm{TA}=$ Tanqua Abergele, $\mathrm{KT}=$ Kola Temben, ${ }^{* * *}=\mathrm{p}<0.001,{ }^{* *}=\mathrm{p}<0.01$; NB: above diagonal is for doe and below diagonal is for buck

\section{DISCUSSION}

\section{Qualitative Traits Description of Goats}

The present finding of a qualitative description of the sampled goat population is in line with Hassen et al. (2012) reported on goats that found in the zones of Amhara region which are nearby to the study areas. Even though, the study goat populations were classified into two groups based on qualitative traits, showed comparable proportion among districts except for coat color and horn shape because of the influences of many genes. Coat color and pattern result of TA and KT districts' population agree with FARM-Africa (1996) report. Whereas the coat colors and patterns result of goats of Adwa is in contrast with the report of FARM-Africa (1996) for Central Highland goat breed that delineated including Adwa district. This difference is due to farmers' selection for the preferred color of their herds.

\section{Body Weight and Linear Measurements of Goats}

Animals of different populations have a different morphological profile (Arandas et al., 2017). The existence of morphological variations within and between goat population is due to the variation of ecological zones accompanying unique climate and vegetation which leads to management and environmental influences (Hagan et al., 2012). Many studies in Ethiopia reported that indigenous goat populations have different body weight and linear measurements in their habitat among districts as well as agroecology (Hassen et al., 2012; Fantahun et al., 2013). The present findings of goats in Adwa district are comparable in body weight $(27.88 \mathrm{~kg})$, body length $(63.15 \mathrm{~cm})$, and height at withers $(68.63 \mathrm{~cm})$ of indigenous goats in South-North Wollo, reported by Hassen et al. (2012).

Sexual size dimorphism is common in all mammalian species and most literature stated that exhibited in goats (Ghafouri-Kesbi \& Notter, 2016; Rotimi et al., 2017). Similarly, the current finding shows a significant effect on body weight and linear measurements with the heaviness and larger sized of bucks than does. Age also another factor, body weight, and linear body measurements increased as the age increased. This effect is related to the high deposition of fat and skeletal development. In the current study, body weight and most considered linear measurements were increased with age. This finding agrees with Sowande et al. (2010) report on West African Dwarf Goat. 
Table 7. Udder and scrotal measurements

\begin{tabular}{|c|c|c|c|c|c|c|c|c|}
\hline \multirow{3}{*}{$\begin{array}{c}\text { Fixed } \\
\text { variables }\end{array}$} & \multirow{3}{*}{$\mathrm{N}$} & \multicolumn{7}{|c|}{ Dependent variables } \\
\hline & & RUD & RUL & UC & $\mathrm{TL}$ & SL & SW & SC \\
\hline & & $\mathrm{LSM} \pm \mathrm{SE}$ & $\mathrm{LSM} \pm \mathrm{SE}$ & $\mathrm{LSM} \pm \mathrm{SE}$ & $\mathrm{LSM} \pm \mathrm{SE}$ & $\mathrm{LSM} \pm \mathrm{SE}$ & $\mathrm{LSM} \pm \mathrm{SE}$ & $\mathrm{LSM} \pm \mathrm{SE}$ \\
\hline Overall & 326 & $10.02 \pm 0.21$ & $14.26 \pm 0.26$ & $28.75 \pm 0.59$ & $2.92 \pm 0.06$ & $11.36 \pm 0.91$ & $9.85 \pm 1.81$ & $23.25 \pm 0.67$ \\
\hline $\mathrm{R}^{2}$ & 326 & 0.08 & 0.3 & 0.12 & 0.15 & 0.39 & 0.24 & 0.50 \\
\hline $\mathrm{CV}$ & 326 & 18.94 & 16.46 & 18.01 & 18.91 & 13.21 & 31.90 & 5.09 \\
\hline District & 326 & $* * *$ & ns & $* * *$ & $* * *$ & * & ns & ns \\
\hline TA & 125 & $10.67 \pm 0.28^{\mathrm{a}}$ & $14.62 \pm 0.34$ & $31.12 \pm 0.76^{\mathrm{a}}$ & $2.84 \pm 0.08^{\mathrm{a}}$ & $10.60 \pm 1.04^{\mathrm{a}}$ & $9.31 \pm 2.07$ & $22.72 \pm 0.79$ \\
\hline KT & 95 & $9.98 \pm 0.31^{\mathrm{ab}}$ & $13.91 \pm 0.38$ & $28.19 \pm 0.85^{b}$ & $2.75 \pm 0.09^{a}$ & $10.10 \pm 1.33^{\mathrm{a}}$ & $12.04 \pm 2.65$ & $22.41 \pm 0.98$ \\
\hline Adwa & 106 & $9.41 \pm 0.27^{\mathrm{b}}$ & $14.25 \pm 0.34$ & $26.94 \pm 0.75^{b}$ & $3.15 \pm 0.08^{b}$ & $13.37 \pm 1.14^{\mathrm{b}}$ & $8.20 \pm 2.26$ & $24.62 \pm 0.83$ \\
\hline Age & 326 & ns & ns & ns & $* * *$ & ns & ns & ** \\
\hline 1PPI & 14 & $9.96 \pm 0.70$ & $13.90 \pm 0.87$ & $28.66 \pm 1.93$ & $2.97 \pm 0.20^{\mathrm{ab}}$ & $9.64 \pm 1.16$ & $9.96 \pm 2.30$ & $20.98 \pm 0.85^{\mathrm{a}}$ \\
\hline 2PPI & 52 & $9.90 \pm 0.39$ & $14.24 \pm 0.49$ & $28.07 \pm 1.09$ & $2.54 \pm 0.11^{\mathrm{a}}$ & $12.34 \pm 1.13$ & $11.85 \pm 2.24$ & $23.20 \pm 0.82^{\mathrm{ab}}$ \\
\hline 3PPI & 89 & $10.10 \pm 0.26$ & $14.13 \pm 0.32$ & $28.90 \pm 0.71$ & $3.08 \pm 0.07 \mathrm{~b}$ & $11.35 \pm 1.14$ & $9.72 \pm 2.27$ & $23.04 \pm 0.84^{\mathrm{ab}}$ \\
\hline 4PPI & 171 & $10.12 \pm 0.17$ & $14.77 \pm 0.21$ & $29.36 \pm 0.47$ & $3.07 \pm 0.05^{b}$ & $12.10 \pm 1.49$ & $7.86 \pm 2.96$ & $25.78 \pm 1.09^{b}$ \\
\hline
\end{tabular}

Note: $\mathrm{TA}=$ Tanqua-Abergele, $\mathrm{KT}=$ Kola-Temben, $\mathrm{RUD}=$ rear udder diameter, $\mathrm{RUL}=$ rear udder length, $\mathrm{UC}=\mathrm{udder}$ circumference, $\mathrm{TL}=$ teat length, $\mathrm{SL}=$ scrotal length, $\mathrm{SW}=$ scrotal width, $\mathrm{SL}=$ scrotal circumference, $\mathrm{ns}=$ non-significant, $\mathrm{PPI}=$ pair of permanent incisors, $1 \mathrm{PPI}=\mathrm{yearling}(1-2$ years old $)$, 2PPI=young-adult (2-3 years old), 3PPI=adult (3-4 years old), 4 PPI $=$ matured $(4-5$ years old $),{ }^{*}=p<0.05,{ }^{* *}=p<0.01,{ }^{* * *}=p<0.001, R^{2}=$ Coefficient of determination for the proportion of variance in the dependent variables by independent variables.

Table 8. Correlation of traits for does (above diagonal) and bucks (below diagonal)

\begin{tabular}{ccccccccccccc}
\hline & BW & BL & HW & CW & RW & CW & RL & HP & RUD/SL & RUL/SW & UC/SC & TL \\
\hline BW & 1 & $0.61^{* * *}$ & $0.58^{* * *}$ & $0.86^{* * *}$ & $0.52^{* * *}$ & $0.47^{* * *}$ & $0.33^{* * *}$ & $0.53^{* * *}$ & $0.24^{* *}$ & $0.36^{* * *}$ & $0.19^{*}$ & $0.24^{* *}$ \\
BL & $0.68^{* * *}$ & 1 & $0.55^{* * *}$ & $0.61^{* * *}$ & $0.33^{* * *}$ & $0.18^{*}$ & $0.33^{* * *}$ & $0.52^{* * *}$ & -0.02 & $0.14^{*}$ & 0.03 & $0.14^{*}$ \\
HW & $0.70^{* * *}$ & $0.67^{* * *}$ & 1 & $0.59^{* * *}$ & $0.35^{* * *}$ & $0.17^{*}$ & $0.2^{* *}$ & $0.72^{* * *}$ & $0.16^{*}$ & $0.3^{* * *}$ & $0.13^{*}$ & $0.3^{* * *}$ \\
HG & $0.87^{* * *}$ & $0.74^{* * *}$ & $0.73^{* * *}$ & 1 & $0.48^{* * *}$ & $0.41^{* * *}$ & $0.32^{* * *}$ & $0.55^{* * *}$ & $0.16^{*}$ & $0.31^{* * *}$ & 0.12 & $0.26^{* * *}$ \\
RW & $0.46^{* *}$ & $0.47^{* *}$ & $0.41^{*}$ & $0.58^{* * *}$ & 1 & $0.4^{* * *}$ & $0.54^{* * *}$ & $0.31^{* * *}$ & $0.24^{* *}$ & $0.27^{* * *}$ & 0.11 & $0.14^{*}$ \\
CW & $0.53^{* * *}$ & $0.42^{*}$ & $0.43^{* *}$ & $0.63^{* * *}$ & $0.59^{* * *}$ & 1 & $0.13^{*}$ & 0.1 & $0.38^{* * *}$ & $0.28^{* * *}$ & $0.27^{* * *}$ & 0.09 \\
RL & $0.30^{*}$ & $0.55^{* * *}$ & $0.3^{*}$ & $0.44^{* *}$ & $0.76^{* * *}$ & $0.27^{*}$ & 1 & $0.28^{* * *}$ & -0.06 & 0.08 & -0.11 & 0.08 \\
HP & $0.71^{* * *}$ & $0.7^{* * *}$ & $0.77^{* * *}$ & $0.74^{* * *}$ & $0.43^{*}$ & $0.43^{*}$ & $0.44^{*}$ & 1 & 0.05 & $0.19^{*}$ & 0.07 & $0.24^{* *}$ \\
RUD/SL & 0.18 & -0.04 & -0.12 & 0.15 & -0.03 & -0.01 & -0.1 & 0.06 & 1 & $0.69^{* * *}$ & $0.72^{* * *}$ & 0.01 \\
RUL/SW & 0.20 & 0.02 & -0.22 & 0.14 & 0.06 & $0.56^{*}$ & -0.49 & -0.07 & 0.17 & 1 & $0.68^{* * *}$ & $0.17^{*}$ \\
UC/SC & $0.67^{* *}$ & $0.67^{* *}$ & 0.39 & $0.64^{* *}$ & 0.38 & 0.06 & $0.44^{*}$ & 0.38 & 0.19 & -0.17 & 1 & -0.019 \\
\hline
\end{tabular}

Note: $\mathrm{BW}=$ body weight, $\mathrm{BL}=$ body length, $\mathrm{HW}=$ height at wither, $\mathrm{CW}=$ chest width, $\mathrm{RL}=$ rump length, $\mathrm{HP}=$ height at pelvic, $\mathrm{RUD}=$ rear udder diameter, $\mathrm{SL}=$ scrotal length, $\mathrm{RUL}=$ rear udder length, $\mathrm{SW}=$ scrotal width, $\mathrm{UC}=$ udder circumference, $\mathrm{TL}=$ teat length, ${ }^{*}=\mathrm{p}<0.05,{ }^{* *}=\mathrm{p}<0.001,{ }^{* * *}=\mathrm{p}<0.0001$, ns= non-significant.

\section{Udder and Scrotal Measurements}

Udder size has a positive relationship with milk production (Pérez-Cabal et al., 2013; Cyrilla et al., 2015). Sperm production is associated with the number of sertoli cells that directly proportional to the testicular size. Goat milk production is among the main purpose of goat raising in TA. Therefore, farmers might have a practice of selecting dairy goat by their udder sizes in TA district. Udder and teat characteristics are important determinants of milk yield and ease of milking or milking ability in dairy animals (Upadhyay et al., 2014). Describing the size of udder and scrotal will be a base for selective breeding.

\section{Correlation of Quantitative Traits}

Most of the considered traits were strongly positively correlated in both sexes. Therefore, the selection of one or more of these traits may increase live body weight of the studied goat populations in respective sex. This current finding is in line with the reports of Hassen et al. (2010) and Zergaw et al. (2016) that body weight with chest girth have a strong relationship in both sexes. Chest girth, height at withers, and height at pelvic are another selection criterion for this goat populations in meat production in addition to body weight. Male reproductive performance has an important contribution to the productivity of goat. Selecting bucks in their body weight, height at pelvic, height at withers and rump length might contribute to breeding soundness of the studied goat population.

\section{CONCLUSION}

Goats found in Central zone of Tigray are morphologically classified in two populations. Goat population found in Adwa districts was distinct in qualitative traits, also heavier and larger than goats found in TA and KT districts. All the linear body measurement and 
body weight of the population are positively correlated in their counterpart with a strong correlation between chest girth and body weight in box sexes and height at pelvic or withers and body weight. In addition, udder measurements of the population have a strong correlation with most of the linear body measurements and body weight. While the scrotal measurements are weakly correlated with most of the linear body measurements.

\section{RECOMMENDATION}

Overall, the similar breeding program could be employed for the goat population in TA and KT districts. While for goat population of Adwa, it is suggested to develop a different breeding program that fit to typical production traits of goats. Variations on udder size measurements suggest including dam-side selection together in selective breeding program.

\section{CONFLICT OF INTEREST}

The authors declare that there is no conflict of interest with any financial, personal, or other relationships with other people or organization related to the material discussed in the manuscript.

\section{REFERENCES}

Arandas, J. K. G., N. M. V. Silva, R. B. Nascimento, E. C. Filho, L. H. A. Brasil, \& M. N. Ribeiro. 2017. Multivariate analysis as a tool for phenotypic characterization of an endangered breed. J. Appl. Anim. Res. 45:152-158. https://doi.or g/10.1080/09712119.2015.1125353

CSA (Central Statistical Agency). 2001. Agricultural Sample Survey (AgSE2001). Report on Area and ProductionTigray Region. Central Statistical Agency of Ethiopia. Addis Ababa, Ethiopia. http://www.csa.gov.et/survey-report/category/140-eth-agss-2001 [06 August 2017]

CSA (Central Statistical Agency). 2007. Census Table of Tigray Region. Central Statistical Agency of Ethiopia. Addis Ababa, Ethiopia. http://www.csa.gov.et/survey-report/ category/146-eth-agss-2007 [10 October 2018]

CSA (Central Statistical Agency). 2017. Report on Livestock and Livestock Characteristics (Private Peasant Holdings). Central Statistical Agency of Ethiopia. (Vol. II). Addis Ababa. http://www.csa.gov.et/survey-report/ category/348-eth-agss-2016 [8 October 2017]

Cyrilla, L., B. P. Purwanto, A. Atabany, D. A. Astuti, \& A. Sukmawati. 2015. Improving milk quality for dairy goat farm development. Med. Pet. 38:204-211. https://doi. org/10.5398/medpet.2015.38.3.204

DAGRIS (Domestic Animal Genetic Resource Information System). 2018. DAGRIS Ethiopia. http://eth.dagris.info [01 September 2018]

Endalew, B. \& Z. Ayalew. 2016. Assessment of the role of livestock in Ethiopia: A Review. Am. J. Sci. Res. 11: 405-410. https://doi.org/10.1002/prot.10156

Fantahun, T., K. Alemayehu, \& S. Abegaz. 2013. Identification and phenotypic characterization of goat ecotypes in the Bench Maji zone, southwestern Ethiopia. Anim. Genet. Resour. 53: 19-26. https://doi.org/10.1017/ S2078633613000325

FAO (Food and Agriculture Organization). 2012. Phenotypic Characterization of Animal Genetic Resources. FAO Animal Production and Health Guidelines No. 11. Rome,
Italy. http://www.fao.org/3/i2686e/i2686e00.htm September 2018]

FARM-Africa. 1996. Goat Types of Ethiopia and Eritrea. Physical description and management systems. FARMAfrica, London, UK, and ILRI (International Livestock Research Institute), Nairobi, Kenya. http://hdl.handle. net/123456789/1544 [25 September 2018]

Gebremariam, T. \& S. Belay. 2016. Livestock feed resources utilization practices in Tanqua-Abergelle district of Tigray, Northern Ethiopia. Trop. Anim. Health Prod. 48: 11831190. https://doi.org/10.1007/s11250-016-1073-y

Ghafouri-Kesbi, F. \& D. R. Notter. 2016. Sex influence on genetic expressions of early growth in Afshari lambs. Arch. Anim. Breed. 59: 9-17. https://doi.org/10.5194/aab-59-9-2016

Hagan, J. K., S. O. Apori, M. Bosompem, G. Ankobea, A. Mawuli, \& H. E. T. Al. 2012. Morphological characteristics of indigenous goats in the coastal savannah and forest ecozones of Ghana. J. Anim. Sci. Adv. 2: 813-821.

Hassen, H., S. Lababidi, B. Rischkowsky, M. Baum, \& M. Tibbo. 2012. Molecular characterization of Ethiopian indigenous goat populations. Trop. Anim. Health Prod. 44: 1239-1246. https://doi.org/10.1007/s11250-011-0064-2

Hosseini, M., H. M. Shahrbabak, M. B. Zandi, \& M. H. Fallahi. 2016. A Morphometric survey among three Iranian Horse breeds with multivariate analysis. Med. Pet. 39: 155-160. https://doi.org/10.5398/medpet.2016.39.3.155

Kosgey, I. S., R. L. Baker, H. M. J.Udo, \& J. A. M. V. Arendonk. 2006. Successes and failures of small ruminant breeding programmes in the tropics : a review. Small Rumin. Res. 61:13-28. https://doi.org/10.1016/j.smallrumres.2005.01.003

Kumar, S., C. A. Rama Rao, K. Kareemulla, \& B. Venkateswarlu. 2010. Role of goats in Livelihood security of rural poor in the less favoured environments. Ind. Jn. Agri. Econ. 65: 760-781.

Lestari, D. A., E. Purbowati, S. Sutopo, \& E. Kurnianto. 2018. Phylogenetical relationships between kejobong goat and other goats based on Mt-DNA D-loop sequence analysis. Trop. Anim. Sci. J. 41: 85-93. https://doi.org/10.5398/ tasj.2018.41.2.85

Leta, S. \& F. Mesele. 2014. Spatial analysis of cattle and shoat population in Ethiopia: Growth trend, distribution and market access. Springer Plus 3:1-10. https://doi. org/10.1186/2193-1801-3-310

Mekuriaw, G.,S. Gizaw, \& A.Tegegne. 2016. Geneticphenotypic and production-system diversity in goat populations in Ethiopia: options for sustainable production (LIVES Working Paper No. 22. Nairobi, Kenya. https://doi. org /10.13140/RG. 2.2.2 5451.34084 [21 September 2018]

MoA (Ministry of Agriculture). 1998. Agro-Ecological Zones of Ethiopia. Minstry of Agriculture of Ethiopia. http://publication.eiar.gov.et:8080/xmlui/handle/123456789/2517?sho $\mathrm{w}=$ full [16 August 2018]

Pérez-Cabal, M. Á., E. Legaz, I. Cervantes, L. F. De La Fuente, R. Martínez, F. Goyache, \& J. P. Gutiérrez. 2013. Association between body and udder morphological traits and dairy performance in Spanish Assaf sheep. Archiv Tierzucht 56:430-442. https://doi.org/10.7482/0003-9438-56-042

Rotimi, E. A., J. O. Egahi, \& A. A. Adeoye. 2017. Body characteristics of West African Dwarf (WAD) goats in Bassa local government area of Kogi State. World Sci. News. 69: 179-189.

Sousa, W. H., M. D. B.Ojeda, O.Facó, \& F. Q. Cartaxo. 2011. Genetic improvement of goats in Brazil: Experiences, challenges and needs. Small Rumin. Res. 98: 147-156. https:// doi.org/10.1016/j.smallrumres.2011.03.032

Sowande, O. S., B. F. Oyewale, \& O. S. Iyasere. 2010. Age- and sex-dependent regression models for predicting the live weight of West African Dwarf goat from body measurements. Trop. Anim. Health Prod. 42:969-975. https://doi. 
org/10.1007/s11250-009-9515-4

Tajebe, S. \& K. Kebede. 2011. Performance and physical body measurement of Abergelle sheep breed in traditional management system of Tigray Regional State, Northern Ethiopia. Int. J. Sci. Nat. 2: 225-230.

Tesfay, Y., A. Gebrelibanos, D. Woldemariam, \& H. Tilahun. 2016. Feed resources availability, utilization and marketing in Central and Eastern Tigray, Northern Ethiopia (LIVES Working Paper 11). Nairobi, Kenya. https://cgspace.cgiar. org/handle/10568/71089 [22 January 2019]

Upadhyay, D., B. H. M. Patel, S. Kerketta, S. Kaswan, S. Sahu, B. Bhushan, \& T. Dutt. 2014. Study on udder morphology and its relationship with production parameters in local goats of Rohilkhand region of India. Indian J. Anim. Res. 48: 615-619. https://doi.org/10.5958/0976-0555.2014.00042.9

Woldu, T., A. Markemann, C. Reiber, P. C. Muth \& A. Valle. 2016. Optimising contributions of goat farming to household economic success and food security in three production systems in Ethiopia. J. Agric. Rural Dev. Trop. Subtrop.117:73-85.

Zergaw, N., T. Dessie, \& K. Kebede. 2016. Description of production system and on-farm phenotypic characterization of Central Highland and Woyto-Guji goat breeds in Ethiopia. Anim. Genet. Resour. 58: 43-51. https://doi. org/10.1017/S2078633615000314 